УДК $347.73(477)$

DOI https://doi.org/10.32849/2663-5313/2020.7.27

\title{
Віктор Мушенок,
}

докт. юрид. наук, дочент,

професор кафедри загальноправових дисциплін

Київського начіонального торговельно-економічного університету

\section{АДМІНІСТРАТИВНО-ПРАВОВІ ЗАСАДИ РЕАЛІЗАЦІЇ ПРИНЦИПІВ МИТНОГО ОФОРМЛЕННЯ В СИСТЕМІ МИТНОЇ ПОЛІТИКИ УКРАЇНИ}

У статті здійснено аналіз законодавчих принципів організащії та здійснення митної справи в Україні та встановлено необхідність удосконалення таких приниипів як важливого складника частини проблеми адміністративно-правового регулювання суспільно-економічних відносин, зокрема, у сфері державного забезпечення зовнішньоекономічної діяльності. У результаті аналізу стану й інструментів адміністративно-правового регулювання митних відносин обгрунтовано внесення змін $і$ доповнень до Митного кодексу України в частині законодавчого закріплення загальних (демократизму, правового плюралізму, пріоритету прав і свобод людини) та спеиіальних приниипів митного оформлення. Визначено метою таких змін забезпечення наближення до європейських стандартів виконання митним органом дій (процедур), що пов'язані із закріпленням результатів митного контролю товарів і транспортних засобів. Отримала подальший розвиток наукова позиція про те, що загальні та спеиіальні приниипи права відіграють важливу роль у правозастосовній діяльності. Зважаючи на це, встановлено, що загальні та спечіальні принципи здійснення митного оформлення в нашій державі повинні бути переорієнтованими на європейські традииії регулювання митних правовідносин. Першочерговим та основоположним приниипом побудови та призначення системи митного оформлення повинен стати покладений в основу законодавства ЄС приниип, сутність яко20 полягає в тому, що подібна дія з боку держави проводиться тільки суворо відповідно до законів, а розв'язання митних спорів має здійснюватися компетентними органами, публічно, з урахуванням пріоритетності прав і свобод людини. Визначено, що будь якого митний спір потрібно вирішувати, керуючись принципами, що виражають найбільш важливі суттєві риси правової системи держави. Використовуючи такий спосіб адміністративно-правового регулювання митних відносин, держава в особі органів державної влади має можливість системно підходити до управління начіональною економікою, до державного управління загалом.

Ключові слова: адміністративно-правові засади, загальні та спеціальні принципи, митна політика, митне оформлення, система митного контролю.

Постановка проблеми. Вимоги ринкової економіки, активний розвиток зовнішньоекономічної діяльності, фінансових, політичних, законодавчих та інших чинників, що впливають на зміст і результати митної діяльності в Україні, зумовлюють потребу комплексного дослідження митних правовідносин представниками сучасної правової науки та вказують на об'єктивну потребу розгляду окремих адміністративних засад такої діяльності.

Подолання кризового стану, у якому перебуває митна справа України, неможливе без удосконалення вітчизняними органами державної законодавчої влади принципів здійснення митної справи. Для України удосконалення принципів формування системи митної діяльності наразі залишається важливою складовою частиною проблеми правового регулювання суспільно-економічних відносин і стане важливим чинником забезпечення подальшого існування та розвитку держави в сучасних світових соціально-політичних умовах.

Особливого значення набуває питання визначення спеціальних принципів під час здійснення митного оформлення, яке у своїй основі становить різновид документального оформлення договору між суб'єктом зовнішньоекономічної діяльності та митним органом щодо переміщення через митний кордон України товарів, предметів тощо.

Аналіз останніх досліджень і публікацій. Особливості проблематики адміністративно-правового регулювання митних відносин і митної політики загалом відображено в наукових працях таких вітчизняних авторів, як В.Б. Авер'янов, О.М. Бандурка, Ю.П. Битяк, І.П. Голосніченко, С.В. Додін, Ф.Л. Жорін, С.В. Ківалов, В.І. Курило, 
П.В. Пашко, С.С. Терещенко та інші. Більш детальний аналіз особливостей правового регулювання митного оформлення частково здійснено такими науковцями. Зокрема, А.О. Брачук розкриває сутність митного оформлення шляхом здійснення комплексного аналізу митних процедур поряд із митним контролем, сплатою митних платежів тощо [1]. П.В. Пашко зазначає, що митні процедури - операції, пов’язані зі здійсненням митного контролю за переміщенням товарів і транспортних засобів через митний кордон, їх митного оформлення, а також зі справлянням передбачених законом податків і зборів [2]. І.Г. Бережнюк розглядає митні процедури як операційний складник митного регулювання [3]. B.I. Царенко та В.О. Хома досліджували сутність і зміст поняття «митна процедура» через установлення його співвідношення з поняттям «митний режим» [4]. М.Г. Шульга зазначає, що митні процедури визначаються технічними нормативами залежно від категорії товарів, видів транспорту, митних режимів, заходів не тарифного регулювання, осіб, які переміщують товари [5].

У працях зазначених і інших авторів тією чи іншою мірою порушувались окремі аспекти проблематики визначення системи принципів державного фінансового контролю (митного, податкового, бюджетного тощо). Водночас цілісного дослідження питань забезпечення саме принципів митного оформлення в діяльності митних органів щодо формування та реалізації митної політики України дотепер не проводилось. Цим підтверджується актуальність, теоретичне і практичне значення проблематики обраного автором дослідження.

Метою статті, зважаючи на розуміння загальної проблеми дослідження, спираючись на напрацьований вітчизняними науковцями передовий досвід у галузі адміністративного права, є спроба здійснення аналізу теоретико-правових засад реалізації принципів, згідно з якими здійснюється виконання митним органом дій (процедур), що пов’язані із закріпленням результатів митного контролю товарів і транспортних засобів як елементу митної ॥ політики України.

Виклад основного матеріалу. Державну політику в будь-якій галузі суспільно-економічних відносин В.І. Андріяш визначає як «напрям дій (або бездіяльність), що обирає державна влада (або орган державної влади, що має повноваження: правові, політичні й фінансові) для вирішення певної проблеми або сукупності взаємозалежних проблем»
[6, с. 14]. Тобто державна політика в галузі митного регулювання - це реакція держави на конкретні питання зовнішньоекономічних відносин, яка покликана погоджувати інтереси, знаходити консенсус, необхідний для стабільності українського суспільства та підтримання міждержавного суспільноекономічного балансу відносин.

Організована митна діяльність спеціалізованих органів державної виконавчої влади є одним із елементів правової держави, основні засади якої закладено в Конституції України. Зокрема, «виключно законами України визначаються засади зовнішніх зносин, зовнішньоекономічної діяльності, митної справи» (п. 9 ст. 92) [7]. У свою чергу, державний митний контроль є складовою частиною фінансового контролю держави за публічними фінансами у різних галузях суспільно-економічної діяльності, а «Кабінет Міністрів України організовує і забезпечує здійснення зовнішньоекономічної діяльності України, митної справи» (п. 8 ст. 116) [7].

Функціонуючи як складова частина державної економічної політики, державна митна політика (відповідно до п. 1 ст. 5. Митного кодексу України (далі - МК України)) - це система принципів і напрямів діяльності держави у сфері захисту митних інтересів та забезпечення митної безпеки України, регулювання зовнішньої торгівлі, захисту внутрішнього ринку, розвитку економіки України та її інтеграції до світової економіки [8].

Отже, важливою проблемою реалізації державної митної політики в Україні, на нашу думку, є проблема вироблення та становлення сучасних принципів системи митного регулювання суспільно-економічних відносин. Актуальність такої постановки питання підтверджує те, що митна політика держави, як інструмент реалізації державної влади, багатозначна за обраними цілями та завданнями. Це, у свою чергу, слугує об'єктивною причиною прояву та належного обгрунтування найістотніших, специфічних, стійких зв'язків і відносин, притаманних системі митного регулювання та закладених в її основних принципах.

Аналізуючи принципи побудови та функціонування фінансової системи держави, М.П. Кучерявенко зазначає, що дефініція «принципи» походить від латинського слова «principium» - початок, закон. Тобто принципи тлумачаться у вітчизняній правовій науці як вихідні, фундаментальні положення, орієнтири, перевірені теорією і практикою [9, с. 43]. За визначенням зазначеного вище науковця, «принципи обгрунтовують, роз'яснюють і відображають зміст 
і взаємозв'язки між об'єктом і суб'єктом фінансових правовідносин» [9, с. 44].

Аналіз викладеної вище наукової позиції та інших наявних позицій дає підстави здійснити узагальнення про те, що принципи формулюються у вигляді певних наукових положень, закріплюються нормативно-правовими актами та застосовуються в теоретичній i практичній державно-управлінській діяльності. На нашу думку, принципи організації та здійснення митного регулювання суспільно-економічних відносин це вироблені спільно науками адміністративного та фінансового права найбільш загальні правила чи стандарти державної митної діяльності.

Зазначимо, що ст. 8 МК України містить положення про принципи здійснення митної справи, тобто законодавець визначає, що митна діяльність держави повинна забезпечуватись належним чином на основі принципів: 1) виключної юрисдикції України на її митній території; 2) виключних повноважень митних органів України щодо здійснення митної справи; 3) законності та презумпції невинуватості; 4) єдиного порядку переміщення товарів, транспортних засобів через митний кордон України; 5) спрощення законної торгівлі; 6) визнання рівності та правомірності інтересів усіх суб'єктів господарювання незалежно від форми власності; 7) додержання прав та охоронюваних законом інтересів осіб; 8) заохочення доброчесності; 9) гласності та прозорості; 10) відповідальності всіх учасників митних відносин [8].

Оскільки митне оформлення $є$ одним з етапів митних процедур як «виконання митних формальностей, необхідних для випуску товарів, транспортних засобів комерційного призначення (ст. 5) [8], то логічним $\epsilon$ розуміння, що визначені у ст. 8 МК України - принципи здійснення митної справи поширюються і на митне оформлення. Адже митне оформлення являє собою обов'язкову процедуру, яку необхідно здійснити під час перетину товаром митного кордону. В основі цієї процедури лежить здійснення, згідно 3 чинним законодавством, декларування даних митним органам держави. Декларування здійснюється шляхом подачі інформації в установленій формі про товари, що ввозяться або вивозяться, із зазначенням мети їх переміщення. Традиційно застосовується письмова форма декларування, яка, у свою чергу, дає змогу подавати інформацію як у паперовому, так і в електронному вигляді.

Варто зазначити, що, на відміну від митного оформлення, принципи здійснення митного контролю законодавчо закріплені у МК
України. Зокрема, ст. 318 (глави 47 розділу XI) [8] визначає загальні принципи здійснення митного контролю, який можливо (у короткому авторському вигляді) охарактеризувати так.

Отже, як вид державної фіскальної діяльності, митний контроль:

1) здійснюється виключно митними органами відповідно до законодавства України;

2) передбачає виконання митними органами мінімуму митних формальностей, необхідних для забезпечення додержання законодавства України з питань митної справи;

3) поширюється на всі товари, транспортні засоби комерційного призначення, які переміщуються через митний кордон України;

4) здійснюється шляхом використання єдиної автоматизованої інформаційної системи митних органів України тощо.

Зважаючи на здійснений аналіз адміністративно-правового регулювання митних відносин, на нашу думку, ст. 246 МК України «Мета митного оформлення» (глава 39 розділу VIII) [8] необхідно перейменувати на «Мета та принципи митного оформлення» та доповнити (пункт 4) переліком загальних і спеціальних принципів такого змісту.

Основними загальними принципами митного оформлення є:

1) принцип демократизму - означає необхідність прийняття рішення з митних питань у певній формі та відповідно до правової процедури, що може забезпечити оптимальне співвідношення економічних інтересів декларанта та держави;

2) принцип правового плюралізму полягає в максимальному врахуванні правових традицій і правової культури у вітчизняній митній сфері, що пов'язано з можливістю забезпечення добровільного виконання податкового обов'язку;

3) принцип пріоритету прав і свобод людини - покладений в основу митної політики, зумовлений сутністю митного оформлення.

Основними спеціальними принципами митного оформлення є його здійснення:

1) на митному кордоні України, що збігається з державним кордоном України;

2)у пунктах пропуску на державному кордоні України, через які здійснюється залізничне, автомобільне, морське, річкове, повітряне, а також інше сполучення, а також у інших районах митної території України;

3) у пунктах, розміщених на митному кордоні України, де він збігається з межами спеціальних митних зон;

4) у зонах митного контролю на території і в приміщеннях підприємств за умови, що 
будуть виконані вимоги забезпечення митного контролю в повному обсязі;

5)у приміщеннях внутрішніх митниць, у яких акредитовані суб'єкти зовнішньоекономічної діяльності.

Здійснений аналіз загальних і спеціальних принципів процесу митного оформлення у механізмі реалізації державної митної політики дає підстави здійснити узагальнення про те, що загальні та спеціальні принципи права відіграють важливу роль у правозастосовній діяльності. Адже у разі відсутності норм права, що регулюють конкретні митні правовідносини, під час вирішення будьякого митного спору в судовому порядку суд може засновувати своє рішення на принципах, що виражають найбільш важливі суттєві риси правової системи держави. Використовуючи такий спосіб адміністративно-правового регулювання суспільних відносин, держава в особі органів державної влади «має можливість системно підходити до управління національною економікою, до державного управління загалом, яке являє собою органічно цілісну систему інструментів, за допомогою яких держава досягає відповідних цілей і вирішення соціально-економічних і політичних проблем» [10, с. 26].

\section{Висновки}

Отже, оформлення митних документів $€$ процесом, який забезпечує формування юридичних фактів у матеріалізованому вигляді, тобто доказів, які можуть бути доказами у справах про порушення митного законодавства. Зважаючи на це твердження, стадія митного оформлення є одним із основних видів митних процедур поряд із стадією збирання митних платежів і притягнення до юридичної відповідальності порушників митного та податкового законодавства. За своєю функціональною сутністю переважна більшість вітчизняних принципів митного регулювання суспільно-економічних відносин, визначених у МК України, має виключно фіскальну спрямованість. Вектор спрямування запропонованих авторських загальних і спеціальних принципів здійснення митного оформлення можна вважати частково орієнтованими на європейські традиції регулювання митних правовідносин. Першочерговим та основоположним принципом побудови та призначення системи митного оформлення повинен стати покладений в основу законодавства $С С$ принцип, сутність якого полягає в тому, що подібна дія з боку держави проводиться тільки суворо відповідно до законів, а розв'язання митних спорів має здійснюватися компетентними органами, публічно, з урахуванням пріоритетності прав і свобод людини. Поряд із запропонованими вище змінами митного законодавства цю дефініцію необхідно долучити до ст. 246 МК України. На нашу думку, зазначені зміни активізують процес подальшої трансформації вітчизняної системи регулювання митних правовідносин за європейськими принципами.

Перспективою подальших наукових досліджень у царині обраної проблематики $€$ подальше адміністративно-правове вдосконалення підприємницької діяльності 3 надання митних послуг, а також подальше визначення кола завдань, функцій і повноважень самостійного центрального органу виконавчої влади, що забезпечує реалізацію державної політики в сфері митної діяльності України.

\section{Список використаних джерел:}

1. Брачук А.О. Категорія «митні процедури» в українському законодавстві: поняття та типологія. Актуальні проблеми політики. 2016. Вип. 58. С. 241-250.

2. Пашко П.В. Понятійний апарат системи забезпечення митної безпеко спроможності. Актуальні проблеми економіки. 2009. № 4 (94). С. 62-68.

3. Бережнюк І.Г. Митне регулювання України: національні та міжнародні аспекти : монографія. Дніпропетровськ : Академія митної служби України, 2009. 543 с

4. Царенко B.I., Хома В.О. Митні процедури: ознаки та поняття. Порівняльно-аналітичне право. 2014. № 3. C. 44-49.

5. Шульга М.Г. Переміщення і пропуск товарів через митний кордон України. Право та управління. / Нац. ун-т держ. податк. служби України. Ірпінь, 2012. № 3. С. 475-486.

6. Андріяш B.I. Державна політика: концептуальні аспекти визначення. Державне управління: удосконалення та розвиток. 2013. № 9. С. 12-17.

7. Конституція України : Основний Закон від 28 червня 1996 р. № 254к/96-BP. URL: https:// zakon.rada.gov.ua/laws/show/254K/96-BP.

8. Митний кодекс України : Закон України від 13 березня 2012 р. № 4495-VI. Відомості Верховної Ради України. 2012. № 44-45, № 46-47, № 48. Ст. 552.

9. Кучерявенко М.П. Податкове право : підручник. Київ : Юрінком Інтер, 2013. 536 с.

10. Антикризове управління національною економікою : монографія / І.Й. Малій, І.Ф. Радіонова, Л.М. Ємельяненко та ін. ; за заг. ред. І.Й. Малого. Київ : КНЕУ, 2017. 368 с. 
Viкtor Mushenok. Administrative and legal principles of implementation of principles of customs clearance in the customs policy system of Ukraine

The article analyzes the legislative principles of organization and implementation of customs in Ukraine and identifies the need to improve such principles as an important part of the problem of administrative and legal regulation of socio-economic relations, in particular, in the field of state support of foreign economic activity. As a result of the analysis of the state and instruments of administrative and legal regulation of customs relations, amendments to the Customs Code of Ukraine are substantiated in terms of legislative consolidation of general (democracy, legal pluralism, priority of human rights and freedoms) and special principles of customs clearance. The purpose of such changes is to ensure approximation to European standards of implementation by the customs authority of actions (procedures) related to the consolidation of the results of customs control of goods and vehicles. The scientific position that general and special principles of law play an important role in law enforcement has been further developed. Based on this, the general and special principles of customs clearance in our country should be reoriented to the European tradition of regulating customs relations. The primary and fundamental principle of construction and purpose of the customs clearance system should be the basis of EU legislation, the essence of which is that such action by the state is carried out only in strict accordance with the law, and customs disputes should be resolved competently bodies, publicly, taking into account the priority of human rights and freedoms. It is determined that any customs dispute should be resolved based on the principles that express the most important essential features of the legal system of the state. Using this method of administrative and legal regulation of customs relations, the state, represented by public authorities, has the opportunity to systematically approach the management of the national economy, public administration in general.

Key words: administrative and legal principles, general and special principles, customs policy, customs clearance, customs control system. 